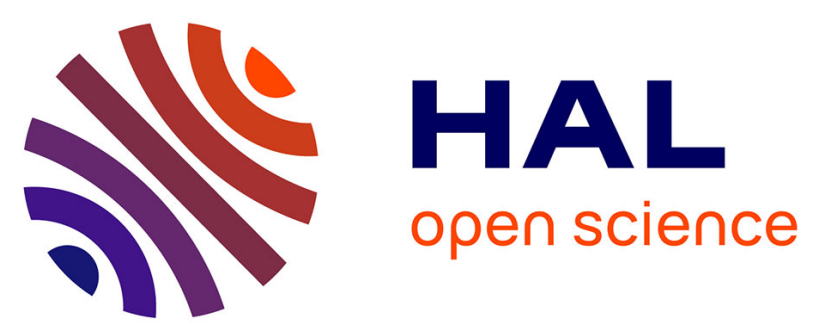

\title{
FINE STRUCTURE OF THE 1s2s2p 4P0 AND 1s2p2 4P DOUBLY EXCITED STATES OF LITHIUMLIKE Si XII
}

J. Buchet, M. Buchet-Poulizac, A. Denis, J. Désesquelles, M. Druetta, S. Martin, Y. Ouerdane

\section{To cite this version:}

J. Buchet, M. Buchet-Poulizac, A. Denis, J. Désesquelles, M. Druetta, et al.. FINE STRUCTURE OF THE 1s2s2p 4P0 AND 1s2p2 4P DOUBLY EXCITED STATES OF LITHIUMLIKE Si XII. Journal de Physique Colloques, 1988, 49 (C1), pp.C1-111-C1-114. 10.1051/jphyscol:1988123 . jpa-00227443

\section{HAL Id: jpa-00227443 https://hal.science/jpa-00227443}

Submitted on 1 Jan 1988

HAL is a multi-disciplinary open access archive for the deposit and dissemination of scientific research documents, whether they are published or not. The documents may come from teaching and research institutions in France or abroad, or from public or private research centers.
L'archive ouverte pluridisciplinaire HAL, est destinée au dépôt et à la diffusion de documents scientifiques de niveau recherche, publiés ou non, émanant des établissements d'enseignement et de recherche français ou étrangers, des laboratoires publics ou privés. 
FINE STRUCTURE OF THE $1 \mathrm{~s} 2 \mathrm{~s} 2 \mathrm{p}{ }^{4} \mathrm{p}^{0}$ AND $1 \mathrm{~s} 2 \mathrm{p}^{2}{ }^{4} \mathrm{p}$ DOUBLY EXCITED STATES OF IITHIUMLIKE Si XII

\author{
J.P. BUCHET, M.C. BUCHET-POULIZAC, A. DENIS, J. DESESQUELLES, \\ M. DRUETTA, S. MARTIN and Y. OUERDANE \\ Laboratoire de spectrométrie Ionique et Moléculaire \\ (CNRS-171), Université tyon $I, 43, B d$ du 11 Novembre 1918 , \\ F-69622 Villeurbanne Cedex, France
}

\begin{abstract}
Résume. La mesure des transitions $1 \mathrm{~s} 2 \mathrm{~s} 2 \mathrm{p}^{4} \mathrm{p}^{0}-1 \mathrm{~s} 2 \mathrm{p}^{2}{ }^{4} \mathrm{p}$ du silicium XII a été réalisée en utilisant la technique faisceau-lame sur l'accélérateur linéaire d'Orsay. La structure fine a eté déterminée arec une bonne précision et l'écart des centres de gravité des multiplets a été mesuré à $\lambda=487.4 \pm 0.1 \AA$. Les résultats sont comparés a des calculs theoriques récents.
\end{abstract}

\begin{abstract}
The $1 \mathrm{~s} 2 \mathrm{~s} 2 \mathrm{p}^{4} \mathrm{p}^{0}-1 \mathrm{~s} 2 \mathrm{p}^{2}$ 4p transitions of Si XII have been investigated using fast in beam spectroscopy in the far ultraviolet. The results for fine structure intervals and term separation represent the highest $Z$ test of electron correlation effects and relativistic contributions in doubly excited states of lithiumlike ions.
\end{abstract}

The $1 \mathrm{~s} 2 \mathrm{~s} 2 \mathrm{p}{ }^{4} \mathrm{p}_{1 / 2,3 / 2,5 / 2}^{0}$ and $1 \mathrm{~s} 2 \mathrm{p}^{2}{ }^{4} \mathrm{P}_{1 / 2,3 / 2,5 / 2}$ states are the lowest multiplets in doubly excited three electron ions. In IS coupling, the system is metastable against autoionization and $X$-ray decay, due to its parity and spin. Main decay is between doubly excited states themselves in the ultraviolet region.

Breit interaction contributes to the fine structure splittings of both multiplets with powers of the nuclear charge as $Z^{4}$ (spin-orbit) and $Z^{3}$ (spin-spin, spin-other orbit). The multiplet separation only increases approximately linearly with $Z$. Best tests of fine structure are given by spectroscopic studies in high nuclear charge elements. In this work on Si XII, we present results in the heaviest ion at present time used for fine structure study of $1 \mathrm{~s} 2 \mathrm{~s} 2 \mathrm{p}{ }^{4} \mathrm{p}^{0}$ and $1 \mathrm{~s} 2 \mathrm{p}^{2}{ }^{4} \mathrm{p}$ states.

Doubly excited states in three electron ions were first detected by Edlen [1]. First measurement of fine structure of $1 \mathrm{~s} 2 \mathrm{~s} 2 \mathrm{p} \mathrm{p}^{4}$ and $1 \mathrm{~s} 2 \mathrm{p}^{2}{ }^{4 \mathrm{p}}$ states has been published by Livingston and Berry [2,3] in C IV, $\mathrm{N} V$ and 0 VI. Then Cheng et al. [4] calculated these structures using a multiconfiguration Dirac-Fock (M.C.D.F.) code, taking only a partial Breit interaction into account. Results are in poor agreement with available experimental determinations. Hata and Grant [5] repeated the calculations employing M.C.D.F.E.A.L. (Energy Average Level) method and found a good agreement with experimental results.

The experiment has been performed at $32.4 \mathrm{MeV}$ using the Orsay LINAC facility with beam intensities of about $7 \mu \mathrm{A}\left(\mathrm{Si}^{3+}\right)$. Stripping by a $20 \mu \mathrm{g} / \mathrm{cm}^{2}$ carbon foil led to charge equilibrium centered on $\mathrm{Si}^{10+}$ and $\mathrm{Si}^{9+}$. The ultraviolet radiation emitted in a direction normal to the excited ion beam was spectroscopically analysed by means of a 2.2 meter McPherson 247 grazing incidence monochromator equipped with a $600 \mathrm{l} / \mathrm{mm}$ grating. Spectrometer incidence angle was $82^{\circ}$ so that blaze was at $210 \mathrm{~A}$. Low spectrometer efficiency, combined with low $\mathrm{Si}^{11^{1+}}$ beam component $(6,3 \%)$, resulted in a weak light signal from quadruplets. Long data collection times led to important background in observed spectra although the dark count rate of our Bendix channeltron detector, used in single counting mode, was less than two counts per minute.

Spectra we observed from $120 \AA$ to $730 \mathrm{~A}$ will be presented and analysed in a further full paper (to be published later). We are interested, in present work, by a partial spectrum recorded between 475 A and $502 \AA$ (Fig. 1), the spectral range containing all the fine structure quadruplet lines. Slit widths were $50 \mu \mathrm{m}$, the full width at half maximum was about $0.5 \AA$ and stepping motor controlled scan increment was 0.1 . Six successive partial spectra have been recorded at same resolution. Spectral 
features appear to be reproducible even in detail. Spectral calibration used in-beam lines of silicium ions. The strong $2 s_{1 / 2}-2 p_{3 / 2}$ resonance line of Si XII, observed in the partial spectrum of figure 1 , was one of these calibration lines. Its wavelength is known to. be $499.398 \pm 0.015 \mathrm{~A}$ from Behring et al. [6], in agreement with semi-empirical calculations of Edlen [7].

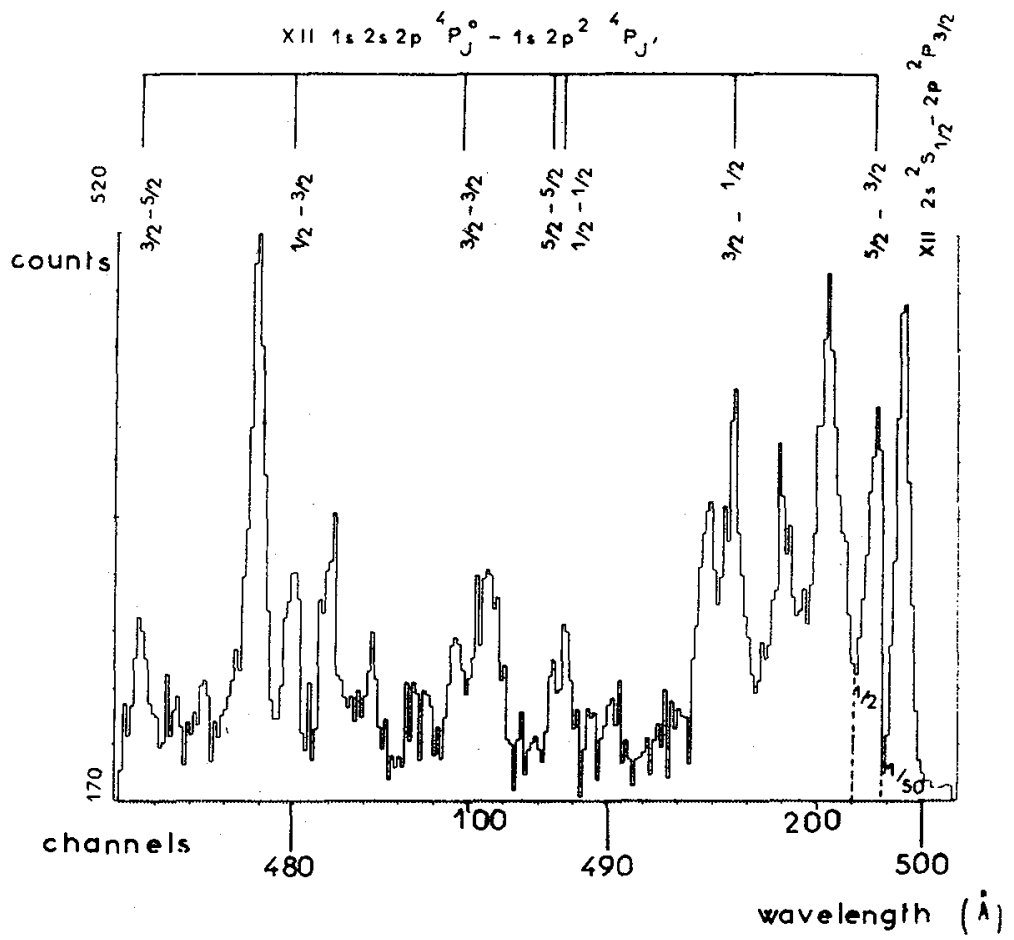

Fig. 1. Spectrum of silicon, at $1.16 \mathrm{MeV} /$ nucleon beam energy, showing the fine structure splitting of the $1 \mathrm{~s} 2 \mathrm{~s} 2 \mathrm{p}^{4} \mathrm{p}^{0} \mathrm{~J}-1 \mathrm{~s} 2 \mathrm{p}^{2}{ }^{4} \mathrm{p}_{\mathrm{J}}$ transition.

Most lines observed between $475 \mathrm{~A}$ and $502 \mathrm{~A}$ have been identified to transitions of multicharged silicon appearing in the second grating order, including transitions between Rydberg states. For example, the intense peak at $478.78 \mathrm{~A}$ has been identified as $\mathrm{Si}$ XIII [4-5] at $2 \times 239.48 \mathrm{~A}$. Line identifications of the $1 \mathrm{~s} 2 \mathrm{~s} 2 \mathrm{p}{ }^{4} \mathrm{p}^{0}-1 \mathrm{~s} 2 \mathrm{p}^{2}{ }^{4} \mathrm{p}$ multiplet were based on isoelectronic comparisons with experimental and theoretical works on ather members of the sequence. From comparison of calculated values [5] and experimental results on $\mathrm{Ne}$ IV [8], Mg X [9], AI XI [10] one can foresee a deviation of about $0.8 \AA$ for $\lambda_{\text {exp }}-\lambda_{\text {th }}$. On this basis, four lines have been easily assigned to ${ }^{4} \mathrm{P}_{3 / 2}^{0}-{ }^{4} \mathrm{P}_{5 / 2},{ }^{4} \mathrm{P}_{1 / 2}^{0}-{ }^{4} \mathrm{P}_{3 / 2},{ }^{4} \mathrm{P}_{3 / 2}^{0}-{ }^{4} \mathrm{P}_{1 / 2}$ and ${ }^{4} \mathrm{P}_{5 / 2}-{ }^{4} \mathrm{P}_{3 / 2}$ transitions. Two of remaining lines, corresponding to ${ }^{4} \mathrm{p}_{1 / 2}^{0}-{ }^{4} \mathrm{p}_{1 / 2}$ and ${ }^{4} \mathrm{p}_{5 / 2}-{ }^{4} \mathrm{P}_{5 / 2}$ components

were weak and not completely separated but they were observed without ambiguity. Finally the ${ }^{4} \mathrm{p}_{3 / 2}{ }^{-}{ }^{4} \mathrm{P}_{3 / 2}$ component is blended by the $5 s-6 \mathrm{p}$ transition of Si XII. Other weak features, not precisely identified, observed at 495.6 and $493.2 \mathrm{~A}$ are probably due to $\mathrm{Si} X$ and $\mathrm{Si}$ XI. They have been also observed by Trabert [15] at lower beam energy $(20 \mathrm{MeV})$. Wavelength and identifications are displayed in Table 1 . Lifetimes of different ${ }^{4} \mathrm{P}$ levels range from 1 to $40 \mathrm{ps}$ [11], resulting in a loss of intensity in the light observed from short line components.

Errors in wavelength determination result from several sources. The uncertainty on calibration line wavelength is very small compared to the spectrometer inaccuracy. For weak Si $X 11{ }^{4} \mathrm{p}^{0}-{ }^{4} \mathrm{P}$ components, the main parameter in wavelength determination precision was statistics. Doppler shifts of short line have also to be taken into account [12]. Errors given in Table I include reproducibility of measurements.

Fine structure and term separation are deduced from experimental wavelength determinations. Results are compared with several calculations in Table II $[4,5,11,13,14]$. 
Table I. Identification of the observed lines in the silicon spectrum of figure 1.

\begin{tabular}{|c|c|c|c|}
\hline Wavelength (A) & & Classification & Comments \\
\hline $475.36 \pm 0.1$ & XII & ${ }^{4} p^{0}{ }_{3 / 2}-{ }^{4} p_{5 / 2}$ & \multirow[b]{2}{*}{ 2nd ordre } \\
\hline $\begin{array}{l}478.97 \\
480.10 \pm 0.05\end{array}$ & $\begin{array}{l}\text { XIII } \\
\text { XII }\end{array}$ & ${ }^{4-5} p_{1 / 2}^{0}-{ }^{4} p_{3 / 2}$ & \\
\hline 481.24 & $\mathrm{X}$ & $2 s 2 p^{2}{ }^{2} s_{1 / 2}-2 p^{3}{ }^{2} D_{3 / 2}^{0}$ & \multirow{4}{*}{$\begin{array}{l}\text { tentative } \\
\text { partially } \\
\text { blended }\end{array}$} \\
\hline $485.23 \pm 0.1$ & XII & ${ }^{4} \mathrm{p}_{3 / 2}^{0}-{ }^{4} \mathrm{p}_{3 / 2}$ & \\
\hline $\begin{array}{l}486.28 \\
488.31 \pm 0.2\end{array}$ & $\begin{array}{l}\text { XII } \\
\text { XII }\end{array}$ & $\begin{array}{l}5 s-6 p \\
{ }^{4} p^{0} \\
5 / 2\end{array}$ & \\
\hline $488.85 \pm 0.2$ & XII & ${ }^{4} p^{0}{ }_{1 / 2}^{3 / 2}-{ }^{4} p_{1 / 2}$ & \\
\hline $\begin{array}{l}493.23 \\
493.95 \pm 0.05\end{array}$ & $\mathrm{XII}$ & ${ }^{4} p^{0}{ }_{3 / 2}-{ }^{4} p_{1 / 2}$ & \\
\hline $\begin{array}{l}495.60 \\
497.00\end{array}$ & & & \\
\hline $498.50 \pm 0.1$ & $\mathrm{XII}$ & ${ }^{4} P_{5 / 2}-{ }^{4} P_{3 / 2}$ & partially \\
\hline $499.398 \pm 0.015$ & XII & ${ }^{2} S_{1 / 2}-{ }^{2} P_{3 / 2}$ & 」 blended \\
\hline
\end{tabular}

The fine structure splitting of Goldsmith is significantly smaller than indicated by the other calculations. The $Z$ expansion data of Vainshtein and Safronova, when combined with the experimental energy for the Si XII $2 p \mathrm{P}_{3 / 2}-2 \mathrm{~s} \mathrm{~S}_{1 / 2}$ transition. agree with our experimental values. Fine structure calculations of Cheng et al. [4] are farther from experiment than more recent data of Chen et al. [11] which take the full Breit interaction into account. Same comments apply to Hata and Grant calculation which is closer to our fine structure experimental results. They add also the radiative corrections which, in fact, are almost independant of $\mathrm{J}$ and mainly shift, as a whole, the $1 \mathrm{~s} 2 \mathrm{~s} 2 \mathrm{p}^{4} \mathrm{p}^{0} \mathrm{~J}$ level.

The calculated term separation of the doubly excited $2 s 2 p{ }^{4} \mathrm{p}_{j}$ and $2 \mathrm{p}^{2}{ }^{4} \mathrm{P}_{J}$ states significantly deviate from the experimental value. This difference can be probably attributed to error on the non relativistic correlation as mentionned by Hata and Grant [5].

Table II. Fine structure and term separation of the doubly excited states $2 s 2 p{ }^{4} p_{J}$ and $2 \mathrm{p}^{2}{ }^{4} \mathrm{p}_{\mathrm{J}}$ of SiXII $\left(\mathrm{cm}^{-1}\right)$.

\begin{tabular}{|c|c|c|c|c|c|c|}
\hline & & & etical da & & & \\
\hline & {$[14]$} & [4] & [13] & [11] & [5] & results \\
\hline $\begin{array}{c}2 p^{24 p} \\
5 / 2-3 / 2 \\
3 / 2-1 / 2 \\
5 / 2-1 / 2\end{array}$ & $\begin{array}{l}4347 \\
2174 \\
6521\end{array}$ & $\begin{array}{l}4073 \\
3629 \\
7702\end{array}$ & $\begin{array}{l}4129.3 \\
3479.4 \\
7608.7\end{array}$ & $\begin{array}{l}4200^{b} \\
3710^{b} \\
7910^{b}\end{array}$ & $\begin{array}{l}4153.9 \\
3649.3 \\
7803.2\end{array}$ & $\begin{array}{l}4230 \pm 100 \\
3690 \pm 70 \\
7920 \pm 60\end{array}$ \\
\hline $\begin{array}{l}2 s 2 \mathrm{p}{ }^{4} 0 \\
5 / 2-3 / 2 \\
3 / 2-1 / 2 \\
5 / 2-1 / 2\end{array}$ & $\begin{array}{l}5364 \\
1788 \\
7152\end{array}$ & $\begin{array}{l}5432 \\
2143 \\
7575\end{array}$ & $\begin{array}{l}5646.9 \\
2170.7 \\
7817.6\end{array}$ & $\begin{array}{l}5600^{b} \\
2175^{b} \\
7775\end{array}$ & $\begin{array}{l}5498.3 \\
2206.7 \\
7705\end{array}$ & $\begin{array}{l}5536 \pm 100 \\
2150 \pm 70 \\
7686 \pm 70\end{array}$ \\
\hline $\begin{array}{c}E_{C G} \\
2 s 2 p-2 p^{2}\end{array}$ & 203832 & 206953 & 204486 & 207039 & 204877 & 205191 \\
\hline$\lambda_{C G}(A)$ & 490.6 & 483.2 & $489.0^{a}$ & $483^{b}$ & 488.1 & 487.4 \\
\hline $\begin{array}{l}\text { [4]: Chen } \\
{[11] \text { : Chen }} \\
\text { a : values } \\
\text { b : values } \\
\text { Cheng. }\end{array}$ & . & $\begin{array}{l}\text { [5]: H } \\
\text { [13]: V } \\
\text { g the ex } \\
\text { rpolatio }\end{array}$ & $\begin{array}{l}\text { and Grat } \\
\text { htein ar } \\
\text { imental } \\
\text { ong the }\end{array}$ & $\begin{array}{l}\text { fronor } \\
\text { Il } 2 \mathrm{~s}- \\
\text { lectron }\end{array}$ & $\begin{array}{l}{[14]:} \\
\text { m differ } \\
\text { uence } f\end{array}$ & $\begin{array}{l}\text { dsmith } \\
\text { ce of Ref. [6] } \\
n \text { the data of }\end{array}$ \\
\hline
\end{tabular}




\section{References}

(1) EDLEN, B., TYREN, F., Nature 143 (1939) 940.

[2] BERRY, H.G., Phys. Scripta 12 (1975) 5.

[3] LIVINGSTON, A.E. BERRY. H.G., Phys. Rev. $A 17$ (1978) 1966

[4] CHENG, K.T., DESCIAUX, J.P. and KIM, Y.K., J. Phys. B11 (1978) L-359.

[5] HATA, J., GRANT, I.P., J. Phys. B16 (1983) 915.

[6] BEHRING, W.E., COHEN, L., FELDMAN, U., DOSCHEX, G.A., Astrophys. J. 203 (1976) 521.

[7] EDLEN, B., Phys. Scripta 19 (1979) 255 EDLEN, B., Phys. Scripta 28 (1983) 51

[8] KNYSTAUTAS, E.J., DRUETTA. M. Phys. Rev. A31 (1985) 2279.

19] TRABERT, E., HELLLMANN, H., HECKMANN, P.H., BASKIN, S., KLEIN, H.A., SILVER, J.D., Phys. Lett. 193 (1982) 76

[10] BUCHET, J.P., BUCHET-POULIZAC, M.C., DENIS, A., DESESQUELIES, J., DRUETTA, M., MARTIN, $S$., GRANDIN, J.P., HENNECART, D., HUSSON, $X$, and LECLER, $D$., J. Physique Lett. 45 (1984) L-361.

TRABBERT, E., HELLMANN, H., HECKMANN, P.H., Z. Phys. A313(1983) 373.

[11] CHEN, M.H., CRASEMANN B., MARK, H., Phys. Rev. A26 (1982) 1441.

[12] BUCHET, J.P., BUCHET-POULIZAC, M.C., DENIS, A., DESESQUELIES, J., DRUETTA, M., KNYSTAUTAS, E., IECLER, D., Nucl. Instrum. Meth 202 (1982) 79.

[13] VAINSHTEIN, L.A., SAFRONOVA, V.I., At. Data Nucl. Data Tables 21 (1978) 49.

[14] GOLDSMITH, S. J., Phys. B7 (1974) 2315.

[15] TRABERT, E., HECKMANN, P.H., BUTTLAR, H.V., BRAND, K., Z. Phys. A279 (1976) 127. 